\title{
Dawid Zdrójkowski
}

Uniwersytet $\mathrm{w}$ Białymstoku e-mail: dzdrojkowski@interia.pl telefon: 501750451

DOI: $10.15290 / \mathrm{mhi} \cdot 2017.16 .02 .10$

\section{Rudolf Schlesinger (1909-1996) Życie i idea}

\section{SUMMARY}

\section{Rudolf B. Schlesinger (1909-1996). Life and idea}

Rudolf Schlesinger (1909-1996) was a brilliant German American scholar of Jewish descent. He was born and raised in Germany, where he received his first law education. Shortly before the outbreak of World War II, he had left his homeland and moved to the US where he became a teacher at Cornell Law School. In recognition of his work at Cornell, Schlesinger received the prestigious William Nelson Cromwell Professorship. In 1975 he left Cornell for Hastings College of the Law, where he continued research there for two decades until his retirement in 1994. Rudolf Schlesinger is well known for his new comparative law methodology, which was elaborated during his stay at Cornell Law School. This methodology, known as case method, was described by Schlesinger in his monumental work Formation of Contracts: A Study of the Common Core of Legal Systems (1968). Schlesinger's ultimate goal in this project, was to identify and define similarities between legal systems. In Schlesinger mind these similarities, known as Common Core, should play a key role in development of both private and international law.

Key words: Comparative law, Cornell project, Common Core, Rudolf B. Schlesinger, history of Polish Law

Słowa kluczowe: prawo porównawcze, Projekt Cornell, wspólny rdzeń, Rudolf B. Schlesinger, historia prawa polskiego

Wybitny amerykański prawnik żydowskiego pochodzenia, Rudolf Berthold Schlesinger (1909-1996), nie licząc krótkich wzmianek¹, nie doczekał się w polskiej literaturze całościowego opracowania skupiającego się na jego życiu 
i koncepcjach. Jest to postać zasługująca na dogłębne studium, tym bardziej, że Schlesinger miał pewne związki z Polską, co szczególnie może zainteresować czytelnika.

Schlesinger urodził się w Monachium w 1909 r.². Rozpoczęte w Genewie studia ukończył na uniwersytecie $\mathrm{w}$ Monachium zdobywając prawniczy dyplom w 1933 r. Dzięki urodzonemu w Stanach Zjednoczonych ojcu Rudolf Schlesinger posiadał amerykańskie obywatelstwo ${ }^{3}$. Początek zawodowej kariery Schlesingera zbiegł się $\mathrm{z}$ dojściem do władzy $\mathrm{w}$ Niemczech nazistów. Przyszły komparatysta pracował wówczas w kancelarii swojego ojca, będąc również współautorem dysertacji Der Wert des geschlossenen Unternehmens und seinSchutz durch die Unterlassungsklage nach $\S 1$ des Gesetzes gegen den unlauteren Wettbewerb ${ }^{4}$ napisanej wraz z uznanym specjalistą z zakresu prawa handlowego Rudolfem Muller-Erzbachem. Ostrzeżony wkrótce przez profesora Erzbacha o planowanym w stosunku do Żydów zablokowaniu możliwości przeprowadzenia przewodu doktorskiego, R. B. Schlesinger w ciągu zaledwie jednego miesiąca napisał i obronił summa cum laude swój przewód doktorski ${ }^{5}$. Sam proces pisania pracy doktorskiej odbył się w sposób niezwykły, jako że R. B. Schlesinger ustnie dyktował asystentowi swoje tezy, ten je zapisywał, a drugi asystent od razu czytał ${ }^{6}$. Po uzyskaniu stopnia doktora jako młody prawnik podjął pracę $\mathrm{w}$ prywatnym banku ${ }^{7}$, gdzie pomagał Żydom likwidować i transferować ich środki pieniężne ${ }^{8}$. Z III Rzeszy wyemigrował do Stanów Zjednoczonych, według jednych źródeł ${ }^{9}$ w 1938 r., krótko po nocy kryształowej, według

2 D. I. Levine, Professor Rudolf B. Schlesinger: An Affectionate Tribute, "Hastings International and Comparative Law Review" 1997, nr 20, s. 219. Zob. https://repository.uchastings.edu/cgi/viewcontent. cgi?article $=1399 \&$ context=faculty_scholarship (03.12.2017).

3 U. Mattei, The Comparative Jurisprudence of Schlesinger and Sacco, [w:] Rethinking the Masters of Comparative Law, red. A. Riles, Oxford-Portland Oregon 2001, s. 240. Zob. https://books.google.pl/ books?id=IrzbBAAAQBAJ\&printsec=frontcover\&hl=pl\#v=onepage\&q\&f=false (03.12.2017).

4 Praca z zakresu ochrony wartości zamkniętego przedsiębiorstwa, w warunkach nieuczciwej konkurencji. Egzemplarz jest dostępny w bibliotece The Hastings College of the Law (za: R. M. Buxbaum, Rudolf Schlesinger - 1909-1996, "American Journal of Comparative Law" 1997, nr 1, s. 1). Zob. http://scholarship.law.berkeley.edu/cgi/viewcontent.cgi?article=2009\&context=facpubs (20.11.2017).

5 B. F. Willcox, Rudolf B. Schlesinger World Lawyer, “Cornell Law Review" 1975, nr 60, s. 919. Zob. http://scholarship.law.cornell.edu/clr/vol60/iss6/1 (26.11.2017); R. M. Buxbaum, op. cit., s. 2. Zob. http://scholarship.law.berkeley.edu/cgi/viewcontent.cgi?article=2009\&context=facpubs (20.11.2017).

6 R. M. Buxbaum, op. cit., s. 2. Zob. http://scholarship.law.berkeley.edu/cgi/viewcontent.cgi?article= 2009\&context=facpubs, (20.11.2017).

7 B. F. Willcox, op. cit., s. 920. Zob. http://scholarship.law.cornell.edu/clr/vol60/iss6/1 (26.11.2017); R. M. Buxbaum, op. cit., s. 2. Zob. http://scholarship.law.cornell.edu/clr/vol60/iss6/1 (20.11.2017).

8 http://www.nytimes.com/1996/11/22/us/rudolf-schlesinger-87-expert-on-the-world-s-legal-syste ms.html (9.12.2017).

9 R. M. Buxbaum, op. cit., s. 2. Zob. http://scholarship.law.berkeley.edu/cgi/viewcontent.cgi?article= 2009\&context=facpubs (21.11.2017). 
innych ${ }^{10}$ natomiast jego statek odpłynął z Europy dopiero w grudniu 1939 r. $\mathrm{Z}$ nieopublikowanych za życia wspomnień R. B. Schlesingera wiadomo, że umożliwił mu to fakt posiadania dzięki ojcu amerykańskiego obywatelstwa ${ }^{11}$. Należy przypuszczać, że tak długie przebywanie przez Schlesingera w Niemczech było zapewne możliwe jedynie dzięki względnej ochronie, jaką zapewniał mu fakt posiadania owego obywatelstwa.

Po przybyciu do Ameryki R. B. Schlesinger początkowo nauczał w nowojorskiej szkole Dalton dla dziewcząt ${ }^{12}$. Szybko jednak ją opuścił i przybył do Columbia Law School, którą to ukończył w 1942 r. Fakt zdobycia pełnego prawniczego wykształcenia zarówno w Niemczech, jak i w Stanach Zjednoczonych, posiadających przecież odmienny od europejskiego system common law, pozwolił zdobyć R. B. Schlesingerowi dogłębne rozumienie prawa i z pewnością odegrał niebagatelną rolę $\mathrm{w}$ jego przyszłych komparatystycznych badaniach. W trakcie studiów R. B. Schlesinger został również redaktorem naczelnym "Columbia Law Review”, prestiżowego czasopisma wydawanego i publikowanego przez studentów Columbia School (będąc jednocześnie pierwszym nierodowitym użytkownikiem języka angielskiego na tym stanowisku $\left.{ }^{13}\right)$. W następnych latach R. B. Schlesinger podejmował się różnych zajęć, m.in. wygrywając prestiżowy konkurs na asystenta Irvinga Lehmana, sędziego New York Supreme Court. Po roku pracy jako asystent został sekretarzem prawnym tego sądu, a w następnych latach pracował także $\mathrm{w}$ renomowanych nowojorskich kancelariach Milbank, Tweed oraz Hadley \& McCloy. Ostatecznie, odrzucając propozycję partnerstwa ze strony swojego kolegi Josepha Kaskella ${ }^{14}$, R. B. Schlesinger w 1948 r. powrócił do pracy naukowej, wiążąc się z Cornell Law School, z którą jest obecnie nierozerwalnie kojarzony. Wynika to z faktu, że właśnie w Cornell Law School R. B. Schlesinger zapoczątkował swój sztandarowy Cornell Common Core Project.

Celem projektu było wypróbowanie i rozpropagowanie nowej, opracowanej przez Schlesingera, metody badań w komparatystyce prawniczej, dążącej do odkrycia wspólnego rdzenia wielu systemów prawnych. Metoda polega na spotkaniu prawników reprezentujących różne systemy prawne, ale obeznanych z tą samą gałęzią prawa. Następstwem spotkania i dyskusji jest opra-

10 U. Mattei, op. cit., s. 241. Zob. https://books.google.pl/books?id=IrzbBAAAQBAJ\&printsec=front cover\&hl=pl\#v=onepage \&q\&f=false (03.12.2017).

11 R. M. Buxbaum, op. cit., s. 2. Zob. http://scholarship.law.berkeley.edu/cgi/viewcontent.cgi?article= 2009\&context=facpubs (20.11.2017).

12 D. I. Levine, op. cit., s. 219. Zob. https://repository.uchastings.edu/cgi/viewcontent.cgi?article= 1399\&context=faculty_scholarship (03.12.2017).

13 U. Mattei, op. cit., s 240. Zob. https://books.google.pl/books?id=IrzbBAAAQBAJ\&printsec=front cover\&hl=pl\#v=onepage\&q\&f=false (03.12.2017).

14 R. M. Buxbaum, op. cit., s. 2. Zob. http://scholarship.law.berkeley.edu/cgi/viewcontent.cgi?article= 2009\&context=facpubs (20.11.2017). 
cowanie raportu, w którym wskazuje się różnice i podobieństwa w sposobie rozstrzygnięcia konkretnego zagadnienia przez szereg systemów prawnych, z których wywodzą się opracowujący go prawnicy. Wywiedzione podobieństwa stanowić miały zdaniem Schlesingera wspomniany wspólny rdzeń - common core ${ }^{15}$. W ówczesnej komparatystyce prawniczej było to podejście rewolucyjne, jako że wcześniejsze badania komparatystyczne prowadzone były w oderwaniu od rozwiązania konkretnego topicu prawnego, skupiając się bardziej na zagadnieniach ogólnych, a tym samym ograniczając pole do wyciągnięcia odpowiednich porównawczych wniosków. Sam R. B. Schlesinger wskazał trzy generalne cele, $\mathrm{w}$ których dostrzegał potencjalne zastosowanie swojej metody badawczej: rozwój materiałów naukowych używanych w szkołach prawniczych na kursach komparatystyki, wsparcie dla nowo tworzonych systemów prawnych, w szczególności krajów nowo powstałych, a więc nieposiadających jeszcze skodyfikowanego prawa, wreszcie zaś jego metoda miała również pomóc $\mathrm{w}$ rozwoju prawa międzynarodowego ${ }^{16}$.

W kontekście ostatniego zastosowania metody R. B. Schlesingera należy wskazać treść art. 38 statutu Międzynarodowego Trybunału Sprawiedliwości (MTS), zawierającego katalog źródeł prawa stosowanych przez MTS przy orzekaniu. W punkcie c) wskazane zostały „zasady ogólne prawa, uznane przez narody cywilizowane" - general principles of law recognised by civilised nations. Ze względu na przyjętą $\mathrm{w}$ artykule systematykę należy uznać, że MTS powinien mieć na uwadze zasady ogólne prawa dopiero wtedy, gdy w dostarczeniu rozstrzygnięcia zawiodą wcześniej wymienione źródła tj. konwencje i zwyczaj międzynarodowy. Zasadne będzie zauważyć, że sama konstrukcja tego artykułu spotkała się w literaturze ze sporą krytyką. Przede wszystkim kontrowersje wywołały kwestie: kto i jak udziela uznania dla wzmiankowanych zasad, jakie jest praźródło z którego należy je czerpać, a także które narody są cywilizowane, a które nie są ${ }^{17}$. Obecnie przeważają tendencje do traktowania art. 38 statutu MTS wyłącznie w znaczeniu historycznym, lub też przyjmowania, że wszystkie narody są cywilizowane. Rudolf B. Schlesinger uważał, że ustalony dzięki jego badaniom common core dostarczy odpowiedzi na pytanie, co należy rozumieć przez „zasady ogólne prawa, uznane przez narody cywilizowane", a tym samym odegra rolę w tworzeniu nowego,

15 W. C. Whitford, Formation of contracts: A study of the common core of the legal system, 1970, s. 301. Zob. https://sites.temple.edu/lawreview/files/2014/09/1970_Formation-of-Contracts-Review.pdf (20.11.2017).

16 D. E. Claudy, Cornell Law Review. Formation on Contracts a Study of the Common Core of Legal Systems, "Cornell Law Review" 1969, nr 54, s. 486. Zob. http://scholarship.law.cornell.edu/cgi/viewcontent. cgi?article $=3761 \&$ context $=$ clr $(26.11 .2017)$.

17 T. Jasudowicz, O zasadach ogólnych prawa uznanych przez narody cywilizowane - garść refleksji, 1997, s. 144-145. Zob. https://repozytorium.umk.pl/bitstream/handle/item/4663/Jasudowicz_20.pdf ?sequence=1 (09.12.2017); W. Góralczyk, Prawo międzynarodowe publiczne w zarysie, Warszawa 1977, s. 75-75; S. E. Nahlik, Wstęp do nauki prawa międzynarodowego, Warszawa 1967, s. 383-384. 
międzynarodowego systemu prawnego ${ }^{18}$. Uzasadnieniem tego miał być fakt, że wywiedzione podobieństwa pojawiające $\mathrm{w}$ różnych systemach prawnych muszą z samej rzeczy być elementami powszechnie akceptowanymi. Warto również dodać, że R. B. Schlesinger utożsamiał general principles of law z common core i w pewnym zakresie posługiwał się tymi terminami zamiennie ${ }^{19}$. Autor Cornell Project nadto uważał, że przystępowanie państw do organizacji międzynarodowych jest pewną formą kontraktu, dlatego istnieje zapotrzebowanie na nowy, międzynarodowy system prawny, jako że żadne z państw członkowskich nie zgodziłoby się na podporządkowanie systemowi krajowemu innego państwa członkowskiego.

Zagadnieniem wybranym w Cornell Project przy pierwszym badaniu nowych metod komparatystycznych zostało bliskie zainteresowaniom Schlesingera zagadnienie zawierania umów. Uzasadnić to należy, po pierwsze, uniwersalnym, powszechnym charakterem wybranego zagadnienia, a po drugie jego potencjalnym praktycznym zastosowaniem ${ }^{20}$. Pewne kontrowersje wywołał dobór państw, na podstawie których systemów prawnych miano poszukiwać wspólnego rdzenia prawa. Biorąc pod uwagę szczególne nadzieje Schlesingera związane z art. 38 statutu MTS musiały to być systemy prawne "cywilizowanych narodów". Początkowo, po przestudiowaniu zasad obowiązujących w różnych systemach, do udziału w projekcie wybrano prawników reprezentujących systemy prawne Anglii, Stanów Zjednoczonych, Szwajcarii, Indii, Włoch, Francji, Niemiec, Austrii, ówczesnej Południowej Afryki oraz Polski. Później do początkowych 10 krajów dołączono do projektu również wiele innych krajów, mianowicie państw pozostających pod wpływem angielskiego prawa (dawne kolonie), a także kilkanaście państw bloku wschodniego. Przewidziano również udział Egiptu i Hiszpanii, jednak specjaliści z tych systemów prawnych opuścili projekt przed jego zakończeniem z przyczyn prywatnych i R. B. Schlesinger nie zdecydował się umieścić $\mathrm{w}$ raporcie końcowym wniosków z tych dwóch systemów.

Zaproszenie do udziału w projekcie krajów bloku wschodniego, a zwłaszcza Polski, już na początkowym etapie, wywołało pewną polemikę, jako że część prawników nie uważała, by wyniki osiągnięte w tychże państwach

18 R. B. Schlesinger, Research on the General Principles of Law Recognized by Civilized Nations, "American Journal of International Law" 1957, s. 734. Zob. http://www.jstor.org/stable/2195351?origin=cross ref\&seq=1\#page_scan_tab_contents (03.12.2017); W. C. Whitford, op. cit., s. 302. Zob. https://sites. temple.edu/lawreview/files/2014/09/1970_Formation-of-Contracts-Review.pdf (20.11.2017).

19 U. Drobnig, A Memorial Address for Rudolf Schlesinger, [w:] The Common Core of European Private Law red. M Bussani. U. Mattei, 2002, s. 31. Zob. https://books.google.pl/books?id=5qKk2CGKj0YC\& $\mathrm{pg}=\mathrm{PA} 29 \& \mathrm{dq}=$ rudolf $+\mathrm{b} .+$ schlesinger\&hl$=\mathrm{pl} \& \mathrm{sa}=$ X\&ved=0ahUKEwi4l8aIm9zXAhUmIJoKHVhwB MQQ6AEIXjAH\#v=onepage\&q=rudolf\%20b.\%20schlesinger\&f=false (26.11.2017).

20 A. D. Austin, Formation of Contracts by Rudolf B. Schlesinger, "Case Western Reserve Law Review" 1969, nr 20, s. 942. Zob. https://scholarlycommons.law.case.edu/cgi/viewcontent.cgi?article=2761\& context=caselrev $(03.12 .2017)$. 
dały się $\mathrm{w}$ jakikolwiek sposób porównać z krajami zachodnimi. R. B. Schlesinger tłumaczył swoją decyzję faktem ciągłego obowiązywania w zakresie prawa cywilnego przedwojennych, kapitalistycznych uregulowań (ciągle obowiązywał polski kodeks zobowiązań z 1933 r.). Drugim argumentem były następujące, zdaniem Schlesingera, coraz większe podobieństwa $\mathrm{w}$ sposobie zarządzania państwowych przedsiębiorstw krajów bloku wschodniego oraz przedsiębiorstw krajów kapitalistycznych ${ }^{21}$. Po wybraniu krajów partycypujących $\mathrm{w}$ projekcie należało wyselekcjonować prawników mających reprezentować dany system prawny. Wybrani zostali, prócz R. B. Schlesingera, P. Bonassies, G. Gorla, J. Leyser, W. Lorenz, I. Macneil, K. Neumayer, I. Saxena oraz W. J. Wagner ${ }^{22}$. Rudolf B. Schlesinger posługiwał się przy wyborze dwoma kryteriami, po pierwsze, mieli to być specjaliści zarówno w teorii, jak i w praktyce prawa, po drugie, preferował, by dla celów komparatystycznych posiadali oni znajomość więcej niż jednego systemu prawnego. W praktyce w kilku przypadkach nie udało się dotrzymać tych luźnych kryteriów - ekspert mający reprezentować Południową Afrykę wykształcenie prawnicze odebrał w Niemczech, a pracował $\mathrm{w}$ Australii. Podobnie wybrany jako reprezentant Polski prof. Wieńczysław J. Wagner, wówczas pracujący na Indiana University School of Law, w Polsce nie przebywał od czasu zakończenia II wojny światowej. Sam prof. Wagner wykształcenie odebrał jeszcze przed II wojną światową na Uniwersytecie Warszawskim, był weteranem powstania warszawskiego i porucznikiem Narodowej Organizacji Wojskowej oraz Armii Krajowej ${ }^{23}$.

Warto w tym momencie uczynić dygresję i zauważyć, że znajomość Schlesingera oraz Wagnera trwała przez wiele lat, a 5 maja 1972 r. ukazała w "Cornell Law Review" recenzja książki pod red. W. Wagnera Polish Law Throughout the Ages ${ }^{24}$ dokonana właśnie piórem R. B. Schlesingera. Artykuł ten oddaje poglądy amerykańskiego komparatysty na temat rozwoju polskiego prawa, co może zainteresować polskiego czytelnika, jak również $\mathrm{w}$ dalszym zakresie wyjaśnić motywy decyzji R. B. Schlesingera o uwzględnieniu w pierwszej kolejności polskiego systemu prawnego w Cornell Project. R. B. Schlesinger przede wszystkim zwrócił uwagę na bezprecedensowość pracy J. W. Wagnera, oferującej anglojęzycznemu czytelnikowi po raz pierwszy jednotomowe dzieło, będące źródłem informacji o polskim prawie, jego historii, teraźniejszości i podstawach filozoficznych. Zwraca również uwagę na tendencję zachodnich autorów do ignorowania w swoich pracach słowiańskich systemów prawnych, co

21 W. C. Whitford, op. cit., s. 304. Zob. https://sites.temple.edu/lawreview/files/2014/09/1970For mation-of-Contracts-Review.pdf, (10.12.2017).

22 R. M. Buxbaum, op. cit., s. 3. Zob. http://scholarship.law.berkeley.edu/cgi/viewcontent.cgi?article= 2009\&context=facpubs (20.11.2017).

23 R. Tokarczyk, Zarys biografii Wieńczystawa Józefa Wangera von Igelgrund, [w:] Ze sztandarem prawa przez świat, red. R. Tokarczyk, K. Motyka, Kraków 2002, s. 11-23.

24 Polish Law Throughout the Ages, red. W. J. Wagner, Stanford, California 1970. 
znacząco zawężało jego zdaniem, całościową perspektywę co do postrzegania europejskiego dorobku prawnego.

Rudolf B. Schlesinger jako mające największy oddziaływanie na polskie prawo wymienia prawo rzymskie, kanoniczne, niemieckie oraz kupieckie ${ }^{25}$. Jednocześnie polemizuje jednak z tezą, jakoby Polacy byli jedynie naśladowcami. Rudolf B. Schlesinger nazywa imponującymi wymienione przez Wagnera osiągnięcia polskich akademików, takie jak postulat równości narodów chrześcijańskich i pogańskich, naturalne prawo do samoobrony (wyrażone w art. 51 Karty Narodów Zjednoczonych), czy zakaz stosowania przymusu w stosunku do obywateli, za wyjątkiem sytuacji „ostatecznej potrzeby". R. B. Schlesinger uważał te zasady za polski wkład do współczesnego prawa międzynarodowego. $\mathrm{W}$ dalszej kolejności słynny komparatysta chwalił polską tradycję prawnej ochrony mniejszości religijnych: „W 1367 roku, kiedy w Anglii, Francji i Niemczech wszyscy Żydzi zostali skazani na wygnanie lub śmierć, Kazimierz Wielki przyznał im wolności wyznania, prawo do politycznego samostawienia oraz szereg innych przywilejów"26.

Rudolf B. Schlesinger zauważa również, że polska konstytucja Nihil Novi (1505), zakazująca królowi uchwalania nowych praw bez zgody parlamentu, wyprzedza znacznie finalne ukształtowanie się angielskiej monarchii parlamentarnej w 1689 r. W dalszej kolejności amerykański naukowiec zastanawia się, jak finalnie rozwinąłby się polski system parlamentarny, gdyby nie zniknięcie Polski z mapy Europy w końcu XVIII w. R. B. Schlesinger zwrócił też uwagę na znakomite koncepcje Leona Petrażyckiego, widzącego prawo jako zjawisko o charakterze psychologicznym, a które to później zostały zaakceptowane między innymi przez Roscoe Pounda ${ }^{27}$. W ostatnim fragmencie swojej recenzji, R. B. Schlesinger, prócz zarekomendowania książki J. W. Wagnera potencjalnym czytelnikom, nazywa Polaków dumnym narodem, oraz zdobywa sie na słowa współczucia $\mathrm{w}$ stosunku do naukowców którzy po II wojnie światowej musieli opuścić Polskę. Słowa takie w czasach pozostawania Polski pod wpływem ZSRR należy z pewnością potraktować jako spektakularny i znaczący gest.

Podstawowym celem Cornell Project, jak zostało powiedziane na początku rozważań, było rozstrzygnięcie przez wybranych ekspertów z różnych systemów prawnych, $\mathrm{w}$ jaki sposób dany system rozwiąże konkretny kazus prawniczy (w tym przypadku zawarcie umowy), a następnie przygotowanie generalnego raportu określającego wychwycone różnice i podobieństwa. Oparcie

25 R. B. Schlesinger, Polish Law Throughout the ages, "Cornell Law Review" 1972, nr 57, s. 852. Zob. http://scholarship.law.cornell.edu/cgi/viewcontent.cgi?article=3997\&context=clr (26.11.2017).

26 Ibidem, s. 853.

27 Ibidem, s. 852. Zob. http://scholarship.law.cornell.edu/cgi/viewcontent.cgi?article=3997\&context $=\operatorname{clr}(26.11 .2017)$, s. 853 . 
metodologii na rozwiązaniu konkretnego zagadnienia jest też przyczyną najbardziej popularnej nazwy tej metody komparatystycznej, określanej jak case method. W kwestii wyboru prawa kontraktowego jako tematu projektu uzasadnić to można uniwersalnym, konsensualnym charakterem zobowiązań, jak również jego powszechnym zastosowaniem, zarówno w zakresie umów powszechnie zawieranych $\mathrm{w}$ życiu codziennym, jak i też $\mathrm{w}$ wielkich międzynarodowych transakcjach ${ }^{28}$. Rudolf B. Schlesinger zadał ekspertom za pomocą przygotowanych kwestionariuszy szereg szczegółowych pytań (26 zagadnień), związanych z zawarciem umowy, przykładowo - czy pismo jest oświadczeniem, ofertą, czy zaproszeniem do umowy ${ }^{29}$ ? Kwestią zasadniczą, wynikającą z różnic terminologicznych $\mathrm{w}$ różnych systemach prawnych, było również upewnienie się, że wszyscy eksperci tak samo zrozumieli przedstawione im zagadnienia. Problem ten rozwiązano przez przedstawienie uczestnikom określonych stanów faktycznych, związanych z kwestią zawarcia umowy. Schlesinger przygotowany sposób rozwiązania wątpliwości interpretacyjnych nazwał podejściem faktycznym - factual approach albo case method. Jak później napisał, w trakcie projektu nie nastąpiło ani jedno nieporozumienie natury terminologicznej. Celem nowego podejścia było przedstawienie sytuacji faktycznej możliwie jak najbardziej oderwanej od krajowego czy też lokalnego rozumienia określonych terminów. Można powiedzieć, że głównym atutem tej metody jest fakt, że konkretny kazus jest zawsze rozumiany tak samo ${ }^{30}$. Należy zauważyć, że metoda factual approach została $\mathrm{w}$ pewnym stopniu zapożyczona i dostosowana do własnych badań przez R. B. Schlesingera z antropologii prawa, gdzie już wcześniej została rozwinięta przez Bronisława Malinowskiego, Karla Llewellyna oraz Adamsona Hobela i jest uznawana do dnia dzisiejszego za najbardziej użyteczną metodologię stosowaną w badaniach natury antropologicznej ${ }^{31}$.

W kolejnym etapie eksperci przygotowali pisemne raporty, zawierające oparte na poszczególnych systemach rozwiązania przedstawionych pytań Krajowe raporty (Individual Reports albo National Reports) zostały podzielone na dwie części. Pierwsza część każdego raportu zawierała wprowadzenie do danego systemu prawa, wyjaśnienie doktrynalnego rozumienia, w ramach któ-

28 D. E. Claudy, op. cit., s. 486. Zob. http://scholarship.law.cornell.edu/cgi/viewcontent.cgi?article= $3761 \&$ context $=$ clr $(26.11 .2017)$.

29 W. C. Whitford, op. cit., s. 305. Zob. https://sites.temple.edu/lawreview/files/2014/09/1970_For mation-of-Contracts-Review.pdf (20.11.2017).

30 A. D. Austin, op. cit., s. 945-946. Zob. https://scholarlycommons.law.case.edu/cgi/viewcontent.cgi ?article $=2761 \&$ context $=$ caselrev $(03.12 .2017)$.

31 U. Mattei, op. cit., s. 241. Zob. https://books.google.pl/books?id=IrzbBAAAQBAJ\&printsec=front cover\&hl=pl\# $\mathrm{v}=$ onepage $\& \mathrm{q} \& \mathrm{f}=$ false (03.12.2017); idem, The Copernican Revolution in Jurisprudence: In Loving Memory of Rudolf B. Schlesinger, Mentor and Friend, "Hastings International and Comparative Law Review" 1997, nr 20, s. 227. Zob. https://repository.uchastings.edu/cgi/viewcontent.cgi ?article $=1513 \&$ context=faculty $\_$scholarship $(03.12 .2017)$. 
rego funkcjonuje prawo kontraktowe konkretnego systemu. Druga część raportów krajowych została podzielona według takiej samej systematyki jak późniejszy raport generalny (General Reports), podług treści zadanych pytań. Taka systematyka pozwala późniejszym badaczom projektu szybko zweryfikować i porównać treść odpowiedzi na poszczególne zagadnienia w raportach krajowych oraz raporcie generalnym.

Kolejnym etapem projektu było spotkanie autorów pisemnych raportów w Cornell, by ustnie je przedyskutować oraz spróbować zauważyć różnice i podobieństwa $\mathrm{w}$ sposobie rozwiązania przez poszczególne systemy prawne przedstawionego na początku zagadnienia. Sformułowane $\mathrm{w}$ trakcie dyskusji podobieństwa - common core - zostały następnie opracowane $\mathrm{w}$ formie podpisanego przez wszystkich ekspertów $\mathrm{w}$ drodze konsensu w postaci wspomnianego już wcześniej generalnego raportu. Zaznaczyć trzeba, że podpisani pod raportem eksperci przyjęli za jego treść wspólną odpowiedzialność. Po sporządzeniu generalnego raportu zadaniem poszczególnych ekspertów było także przeformułowanie swoich wcześniejszych, „krajowych” raportów, w sposób odzwierciedlający ich ewentualne zmiany w sposobie myślenia nad przedstawionym zagadnieniem, a także odnoszące się do wniosków wywiedzionych po ustnej dyskusji w generalnym raporcie ${ }^{32}$.

Praca dokonana $\mathrm{w}$ trakcie Cornell Project została przedstawiona przez R. B. Schlesingera $\mathrm{w}$ trzytomowym dziele Formation of Contracts: A Study of the Common Core of Legal Systems. Co ciekawe, ze wspomnień R. B. Schlesingera wiadomo, że początkowo nie planował on opublikować swojej pracy i to dopiero współpracownik uniwersytetu dał kopię książki agentowi wydawnictwa wizytującemu kampus, a sam Schlesinger dowiedział o tym dopiero, gdy książka trafiła do korekty drukarskiej33. Opracowaną przez R. B. Schlesingera metodę uznano za przełomową, oderwaną od wcześniejszego wąskiego ujęcia komparatystyki ${ }^{34}$. Po raz pierwszy $w$ takich badaniach rozszerzono znacznie liczbę poddanych badaniu systemów prawnych (tradycyjnie porównywano dwa systemy). Ujęcie oderwane od charakterystycznego dla wcześniejszej komparatystyki zestawiania i kompilacji pozwoliło na sformułowanie i zdefiniowanie podobieństw i różnic zachodzących pomiędzy znaczną liczbą systemów prawnych. Schlesinger, chcąc sformułować generalne zasady prawa, nie postulował ich hipotetycznego istnienia opartego na jego tezach.

32 W. C. Whitford, op. cit., s. 317. Zob. https://sites.temple.edu/lawreview/files/2014/09/1970_For mation-of-Contracts-Review.pdf (20.11.2017).

33 U. Mattei, The Comparative..., s. 241. Zob. https://books.google.pl/books?id=IrzbBAAAQBAJ\&print $\mathrm{sec}=$ frontcover\&hl$=\mathrm{pl} \# \mathrm{v}=$ onepage $\& \mathrm{q} \& \mathrm{f}=$ false $(03.12 .2017)$.

34 Ibidem, s. 241. Zob. https://books.google.pl/books?id=IrzbBAAAQBAJ\&printsec=frontcover\&hl= $\mathrm{pl} \# \mathrm{v}=$ onepage \&q\&f$=$ false $(03.12 .2017)$. 
Innowacyjne factual approach pozwoliło na sformułowanie owych zasad na podstawie prawdziwych rozwiązań określonych stanów faktycznych. Podejście takie pozwoliło na uniknięcie obecnych we wcześniejszych badaniach o takim charakterze nieporozumień co do treści zadanego pytania i tym samym ograniczenie, a zdaniem R. B. Schlesingera nawet całkowite wyeliminowanie, wątpliwości co do treści postawionego przed ekspertami zagadnienia. Zaznaczyć również należy, że wcześniejsze metody badań komparatystycznych ograniczały się do zwykłego porównywania norm (zasad) z pewnego spektrum systemów prawnych. Dzięki metodologii opracowanej przez R. B. Schlesingera możliwe stało się zaobserwowanie podobieństw ukrytych pod treściowymi i terminologicznymi różnicami systemów prawnych. Należy również zwrócić uwagę, że zastosowana metodologia badań, jak ustna dyskusja ekspertów nad opracowanymi krajowymi raportami, wpłynęła na rozwój i pogłębienie współpracy prawników z różnych krajów. Jest to również nieoceniony wkład w rozwój komparatystyki, jako że badania komparatystyczne mogą przynieść wymierny efekt jedynie dzięki kolektywnemu wysiłkowi. Warto także zauważyć, że wspólny dorobek myśli prawniczej, wyrastanie kodeksów z tych samych historycznych tradycji, opierających sie na tych samych zasadach, został wykazany również w literaturze o charakterze historyczno-przekrojowym ${ }^{35}$.

W 1975 R. B. Schlesinger opuścił Cornell University, by zostać profesorem na Hastings College of Law University of California, gdzie pracował aż do swojej emerytury w $1994 \mathrm{r}^{36}$ Zaznaczyć należy, że nie były to jedyne uniwersytety, z którymi związany był R. B. Schlesinger. Był także profesorem wizytującym na uniwersytetach Columbia oraz Utah ${ }^{37}$. Autor Cornell Project zmarł razem ze swoją żoną Ruth w swoim domu w San Francisco w wieku 87 lat. Według medialnych doniesień para popełniła samobójstwo, z powodu słabnącego zdrowia Ruth Schlesinger ${ }^{38}$. Schlesingerowie mieli dwójkę dzieci oraz siedmioro wnuczą ${ }^{39}$.

W podsumowaniu należy podkreślić rolę, jaką odegrał Rudolf B. Schlesinger $\mathrm{w}$ rozwoju komparatystyki i metodologii badań komparatystycznych. Uczeń Schlesingera, Ugo Mattei w tytule przywoływanego artykułu nazywa ją wręcz przewrotem kopernikańskim w jurysprudencji, co jasno powinno

35 K. Sójka-Zielińska, Historia prawa, Warszawa 2011, s. 11; eadem, Drogi i bezdroża prawa. Szkice $z$ dziejów kultury prawnej Europy, Wrocław, 2012, s. 70.

36 R. M. Buxbaum, op. cit., s. 2. Zob. http://scholarship.law.berkeley.edu/cgi/viewcontent.cgi?article= 2009\&context=facpubs (20.11.2017). B. F. Willcox, op. cit., s. 920. Zob. http://scholarship.law.cornell.edu/clr/vol60/iss6/1 (26.11.2017). http://www.nytimes.com/1996/11/22/us/rudolf-schlesinger-87-expert-on-the-world-s-legal-syste ms.html (03.12.2017); https://www.jweekly.com/1996/11/22/professor-rudolf-schlesinger-wife-ru th-die-together-in-s-f/ (03.12.2017). 
określić skalę nowego podejścia. Badania te, zgodnie z przewidywaniami Schlesingera, nabrały szczególnego znaczenia w rozwoju wspólnego dorobku prawniczego cywilizowanych narodów, co zwłaszcza wiąże się procesami unifikacyjnymi zachodzącymi jeszcze do niedawna w Europie. Nadto, warto zauważyć, że dziedzictwo Schlesingera ciągle trwa. Projekt pod jego patronatem Common Core of the European Private Law - skupiający prawników z wielu krajów, jest kontynuowany pod przewodnictwem włoskich prawników Ugo Mattei oraz Mauro Busaniego ${ }^{40}$.

\section{Bibliografia}

Austin A.D., Formation of Contracts by Rudolf B. Schlesinger, "Case Western Reserve Law Review" 1969, nr 20.

Buxbaum R.M., Rudolf Schlesinger - 1909-1996, "American Journal of Comparative Law" 1997, nr 1.

Claudy D.E., Cornell Law Review. Formation on Contracts a Study of the Common Core of Legal Systems, “Cornell Law Review” 1969, nr 54.

Drobnig U., A Memorial Address for Rudolf Schlesinger, [w:] The Common Core of European Private Law, red. M Bussani. U. Mattei, 2002.

Góralczyk W., Prawo międzynarodowe publiczne w zarysie, Warszawa, 1977.

Jasudowicz T., O zasadach ogólnych prawa uznanych przez narody cywilizowane - garść refleksji, 1997.

Levine I., Professor Rudolf B. Schlesinger: An Affectionate Tribute, "Hastings International and Comparative Law Review" 1997, nr 20,

Mattei U., The Comparative Jurisprudence of Schlesinger and Sacco, w: Rethinking the Masters of Comparative Law, red. A. Riles, Oxford-Portland Oregon 2001.

Mattei U., The Copernican Revolution in Jurisprudence: In Loving Memory of Rudolf B. Schlesinger, Mentor and Friend, "Hastings International and Comparative Law Review" 1997, nr 20.

Nahlik S.E., Wstęp do nauki prawa międzynarodowego, Warszawa 1967.

Polish Law Throughout the Ages, red. W. J. Wagner, Stanford, California 1970.

Schlesinger R.B., Polish Law Throughout the ages, "Cornell Law Review" 1972, nr 57.

Schlesinger R.B., Research on the General Principles of Law Recognized by Civilized Nations, "American Journal of International Law" 1957.

Sójka-Zielińska K., Drogi i bezdroża prawa. Szkice z dziejów kultury prawnej Europy, Wrocław 2012.

40 Zob. http://www.common-core.org/ (10.12.2017). 
Sójka-Zielińska K., Historia prawa, Warszawa 2011.

Tokarczyk R., Komparatystyka prawnicza, Warszawa 2008.

Tokarczyk R., Zarys biografii Wieńczysława Józefa Wangera von Igelgrund, [w:] Ze sztandarem prawa przez świat, red. R. Tokarczyk, K. Motyka, Kraków 2002.

Whitford W.C., Formation of contracts: A study of the common core of the legal system, 1970.

Willcox B.F., Rudolf B. Schlesinger World Lawyer, “Cornell Law Review” 1975, nr 60. 